\section{Two Cases of Anaphylaxis to Tranexamic Acid Confirmed by Drug Provocation Test: What About Skin Tests?}

El Hanache $\mathrm{H}^{1}$, Verdaguer $\mathrm{M}^{2}$, Collin $\mathrm{L}^{1}$, Babin $\mathrm{M}^{3}$, Favrelière $\mathrm{S}^{4}$, Vidal Husser $\mathrm{S}^{5}$, Maissiat $\mathrm{MH}^{6}$, Hoppe $\mathrm{A}^{1}$, Morisset $\mathrm{M}^{1}$ ${ }^{1}$ Allergy Unit, Angers University Hospital, Angers, France ${ }^{2}$ Regional Allergology Center, Poitiers University Hospital, Poitiers, France

${ }^{3}$ Department of Pharmacology-Toxicology and Pharmacovigilance Unit, Angers University Hospital, Angers, France

${ }^{4}$ Department of Pharmacology and Pharmacovigilance Unit, Poitiers University Hospital, Poitiers, France

${ }^{5}$ Department of Anesthesia and Reanimation, Angers University Hospital Angers, France

${ }^{6}$ Department of Anesthesia and Reanimation, Saint Léonard Clinic, Trélazé, France

J Investig Allergol Clin Immunol 2021; Vol. 31(4): 351-353 doi: 10.18176/jiaci.0651

Key words: Tranexamic acid. Anaphylaxis. Allergy. Hypersensitivity. Anesthesia. Skin testing. Drug provocation test.

Palabras clave: Ácido tranexámico. Anafilaxia. Alergia. Hipersensibilidad. Anestesia. Test cutáneos. Prueba de provocación con medicamentos.

The antifibrinolytic agent tranexamic acid (TXA) is a derivative of the amino acid lysine that blocks the lysinebinding sites on plasminogen.

TXA is used to treat heavy bleeding, such as menometrorrhagia, postpartum hemorrhage, and hemophilia. It is also administered to reduce the risk of death in bleeding trauma and traumatic brain injury (CRASH-2 and CRASH-3 [1]) and to prevent excessive blood loss during surgery.

The first case of TXA-induced anaphylaxis was reported in 2004 [2]. Since then, few cases have been reported. Here, we present the results of the first positive drug provocation test (DPT) in TXA-induced anaphylaxis.

The first patient was a 15-year-old girl with a history of asthma and hay fever who was referred to the allergy department for anaphylaxis during knee ligament reconstruction. Preoperative intravenous treatments included $2 \mathrm{~g}$ cefazolin and 1 g TXA (Exacyl) (first exposure). A few minutes later, she developed tachycardia (heart rate, $160 \mathrm{bpm}$ ) and bronchospasm with desaturation. These were treated using saline volume expansion, adrenaline aerosol, and methylprednisolone. Surgery was postponed. Tryptase was not measured.

Two months after the reaction, skin prick tests (SPTs) and intradermal tests (IDTs) were performed according to guidelines [3]. SPTs with iodinated povidone, chlorhexidine, and latex were negative. STP, IDT, and DPT (1 g cumulative dose) with cefazolin were negative.

SPT with TXA (IV Exacyl) (Sanofi-Aventis France) $100 \mathrm{mg} / \mathrm{mL}$ (undiluted) was negative, as were IDTs with TXA $(0.1,1,10 \mathrm{mg} / \mathrm{mL})$. The IDT wheal increased from $3 \mathrm{~mm}$ to
$5 \mathrm{~mm}$ and was surrounded by erythema $(9 \mathrm{~mm}) 20$ minutes later at $10 \mathrm{mg} / \mathrm{mL}$.

After signature of the informed consent form, an oral DPT was performed to assess TXA (Exacyl oral solution, $1 \mathrm{~g} / 10 \mathrm{~mL}$ ), with gradually increasing doses every 20 minutes $(1 \mathrm{mg}$, $10 \mathrm{mg}, 100 \mathrm{mg}, 500 \mathrm{mg}, 1000 \mathrm{mg}$ ). The patient presented with rhinoconjunctivitis, retroauricular itching, abdominal wheals, and cough 20 minutes after the eliciting dose of $100 \mathrm{mg}$ (cumulative dose, $111 \mathrm{mg}$ ). The reaction was treated with dexchlorpheniramine and salbutamol.

The second patient was a 56-year-old man who had undergone knee arthroscopy and was referred for anaphylaxis during total knee replacement. Anesthesia was induced with propofol, sufentanil, atracurium, and ketamine. Dexamethasone, $1 \mathrm{~g}$ TXA (Exacyl) and cefazolin were administrated 20 minutes later. Within 20 minutes, the patient developed hypotension $(57 / 35 \mathrm{mmHg})$, tachycardia (99 bpm), desaturation $(90 \%)$, and erythema, which were treated with saline and colloid volume expanders, $150 \mu \mathrm{g}$ IV noradrenaline, $100 \mu \mathrm{g}$ IV adrenaline, and methylprednisolone. Surgery was postponed. The serum tryptase level had increased to $14.2 \mu \mathrm{g} / \mathrm{L}$ 90 minutes after onset of the reaction (baseline, $4.6 \mu \mathrm{g} / \mathrm{L}$ [normal, $<13.5 \mu \mathrm{g} / \mathrm{L}]$ ). The histamine level was $26.2 \mathrm{nmol} / \mathrm{L}$ during the reaction and $10.1 \mathrm{nmol} / \mathrm{L}$ (normal, $<10 \mathrm{nmol} / \mathrm{L}$ ) 90 minutes after the onset of symptoms.

Six months later, IDTs with propofol $1 \mathrm{mg} / \mathrm{mL}$, sufentanil $0.5 \mu \mathrm{g} / \mathrm{mL}$, atracurium $0.01 \mathrm{mg} / \mathrm{mL}$, ketamine $1 \mathrm{mg} / \mathrm{mL}$, dexamethasone $0.04 \mathrm{mg} / \mathrm{mL}$, and cefazolin $2 \mathrm{mg} / \mathrm{mL}$ were negative. Determination of specific IgE to latex and quaternary ammonium ions was also negative with ImmunoCAP $\left(<0.10 \mathrm{kU}_{\mathrm{A}} / \mathrm{L}\right)$. The DPTs to cefazolin (cumulative dose, $1 \mathrm{~g}$ ) and dexamethasone (cumulative dose, $4 \mathrm{mg}$ ) were negative. SPT was performed with undiluted TXA and IDT with TXA (Exacyl, 10, $100 \mathrm{mg} / \mathrm{mL}$ ). IDT with TXA $100 \mathrm{mg} / \mathrm{mL}$ was positive: the wheal increased from 4 to $10 \mathrm{~mm}$ and was surrounded by erythema ( $45 \mathrm{~mm})$ after 20 minutes.

Intravenous DPT to TXA (Exacyl) was performed once the patient had signed the informed consent document. Six minutes after the $50 \mathrm{mg}$ dose (cumulative dose, $57.2 \mathrm{mg}$ ), the patient developed tachycardia (104 bpm), cough, conjunctivitis, and erythema, which were treated with antihistamine and prednisolone.

Subsequent surgery was performed with propofol, sufentanil, atracurium, ketamine, and cefazolin. No adverse effects were recorded.

Both cases were reported to our regional pharmacovigilance centers.

TXA has been on the World Health Organization (WHO) Model List of Essential Medicines since the 2011 adult edition [4]. In addition to other drugs that affect coagulation, TXA is recommended owing to its efficiency in gynecology, hematology, and surgery. For the past 10 years, increasingly frequent adverse effects, including hypersensitivity, have been reported in VigiBase (http://www.vigiaccess.org), the WHO global database of individual case safety reports. This greater frequency may be associated with the recent recommendations to use TXA in the CRASH studies (CRASH-2 and CRASH-3 [1]). A large study carried out in 2016 in the UK showed that of the various drugs that affect coagulation, TXA was the most used drug $(5.9 \%$ of all cases) in perioperative care [5]. 
Table. Skin Testing and Biological Assessments of Immediate Hypersensitivity to TXA in Previously Published Reports

\begin{tabular}{|c|c|c|c|c|c|}
\hline Age & Procedure & Immediate-Type & Skin Test Results & In Vitro & Reference \\
\hline 69 & $\begin{array}{l}\text { Total hip } \\
\text { arthroplasty }\end{array}$ & Flushing, cardiac arrest & $\begin{array}{l}\text { SPT positive with } 1 \mathrm{mg} / \mathrm{mL} \\
\text { IDT positive with } 0.01 \mathrm{mg} / \mathrm{mL}\end{array}$ & BHRA: negative & [8] \\
\hline 80 & $\begin{array}{l}\text { Total knee } \\
\text { replacement }\end{array}$ & Hypotension, tachycardia & $\begin{array}{l}\text { SPT positive with } 100 \mathrm{mg} / \mathrm{mL} \\
\text { IDT positive with } 0.2 \mathrm{mg} / \mathrm{mL} \\
\text { SPT and IDT negative in } \\
5 \text { healthy controls with } 100 \mathrm{mg} / \mathrm{mL}\end{array}$ & $\begin{array}{l}\text { TXA-specific } \\
\text { IgE negative }\end{array}$ & {$[7]$} \\
\hline 72 & $\begin{array}{l}\text { Coronary artery } \\
\text { bypass }\end{array}$ & $\begin{array}{l}\text { Flushing, desaturation, } \\
\text { hypotension, tachycardia }\end{array}$ & $\begin{array}{l}\text { SPT positive with } 100 \mathrm{mg} / \mathrm{mL} \\
\text { SPT negative in } 10 \text { healthy controls } \\
\text { with } 100 \mathrm{mg} / \mathrm{mL}\end{array}$ & BHRA: negative & {$[2]$} \\
\hline 58 & Unknown & Unknown & $\begin{array}{l}\text { SPT negative with } 100 \mathrm{mg} / \mathrm{mL} \\
\text { IDT positive with } 100 \mathrm{mg} / \mathrm{mL} \\
\text { IDT negative with } 10 \mathrm{mg} / \mathrm{mL}\end{array}$ & None & [9] \\
\hline 15 & $\begin{array}{l}\text { Posterior spinal } \\
\text { fusion }\end{array}$ & Hypotension, tachycardia & $\begin{array}{l}\text { SPT positive with } 100 \mathrm{mg} / \mathrm{ml} \\
\text { IDT positive with } 10 \mathrm{mg} / \mathrm{mL}\end{array}$ & None & {$[10]$} \\
\hline
\end{tabular}

Abbreviations: BHRA, serum basophil histamine release assay; IDT, intradermal test; SPT, skin prick test; TXA, tranexamic acid.

Previously published reports of anaphylaxis to TXA have been based on the clinical history, skin tests, and in vitro tests (Table), although DPTs have never been performed in cases of anaphylaxis. Spanish guidelines recommend SPT with undiluted TXA and IDT with TXA $10 \mathrm{mg} / \mathrm{mL}$ as the nonirritant concentrations [6].

We initially performed IDTs with TXA up to $10 \mathrm{mg} / \mathrm{mL}$ in the first case and up to $100 \mathrm{mg} / \mathrm{mL}$ in the second case and performed DPTs owing to discrepancies in skin testing recommendations. Subsequently, in order to address this gap in the literature, we performed IDTs with several TXA concentrations in healthy controls. We started with TXA $100 \mathrm{mg} / \mathrm{mL}$ but rapidly stopped because results for all 6 of the healthy controls were positive. We then administered TXA $10 \mathrm{mg} / \mathrm{mL}$ but again stopped because of 2 positive results from 11. Finally, we tested TXA $2 \mathrm{mg} / \mathrm{mL}$, and 14 of 14 results were negative. Despite data from previous studies [6,7], we showed that IDT with undiluted TXA should not be performed because of the fact that the concentration is irritant and the results of IDT with TXA $10 \mathrm{mg} / \mathrm{mL}$ should be interpreted carefully because of a risk of false positives. If TXA-induced anaphylaxis is suspected, we suggest performing SPT with undiluted TXA and IDT up to $2 \mathrm{mg} / \mathrm{mL}$, followed, if negative, by a DPT.

Given the presence of similar chemical structures and potential common epitopes, other lysine derivatives such as aminocaproic acid should be avoided [8]. Etamsylate seems to be a safe alternative [7-9].

Our study draws attention to the growing risk of anaphylaxis resulting from more frequent use of TXA, especially for trauma patients and in cardiac and orthopedic surgery. Each case should be referred to an allergist to perform appropriate skin tests and DPT if needed.

\section{Acknowledgments}

We are grateful to Manon BOUYE and Thomas BRIGLY for their help in the preparation of the manuscript.

\section{Funding}

The authors declare that no funding was received for the present study.

\section{Conflicts of Interest}

The authors declare that they have no conflicts of interest.

\section{References}

1. CRASH-3 trial collaborators. Effects of tranexamic acid on death, disability, vascular occlusive events and other morbidities in patients with acute traumatic brain injury (CRASH-3): a randomised, placebo-controlled trial. Lancet. 2019;394:1713-23.

2. Lucas-Polomeni M-M, Delaval Y, Menestret P, Delaval P, Ecoffey C. Un cas de choc anaphylactique à l'acide tranexamique (Exacyl囚). Ann Fr Anesth. 2004;23:607-9.

3. Brockow K, Romano A, Blanca M, Ring J, Pichler W, Demoly P. General considerations for skin test procedures in the diagnosis of drug hypersensitivity. Allergy. 2002;57:45-51.

4. WHO Model Lists of Essential Medicines, 17th ed, March 2011. http://www.who.int/medicines/publications/essentialmedicines/ en/ Accessed June 2020.

5. Marinho S, Kemp H, Cook TM, Farmer L, Farooque S, Lucas DN, et al. Cross-sectional study of perioperative drug and allergen exposure in UK practice in 2016: the 6th National Audit Project (NAP6) Allergen Survey. Br J Anaesth. 2018;121:14658. https://doi.org/10.1016/j.bja.2018.04.016.

6. Laguna J, Archilla J, Doña I, Corominas M, Gastaminza G, Mayorga C, et al. Practical Guidelines for Perioperative Hypersensitivity Reactions. J Investig Allergol Clin Immunol. 2018;28:216-32.

7. Bansal RA, Nicholas A, Bansal AS. Tranexamic Acid: An Exceedingly Rare Cause of Anaphylaxis during Anaesthesia. Case Reports Immunol. 2016;2016:1-2. 
8. Li PH, Trigg C, Rutkowski R, Rutkowski K. Anaphylaxis to tranexamic acid-a rare reaction to a common drug. J Allergy Clin Immunol Pract. 2017;5:839-41.

9. Imbesi $S$, Nettis $E$, Minciullo PL, Leo E, Saija A, Vacca A, et al. Hypersensitivity to tranexamic acid: a wide spectrum of adverse reactions. Pharm World Sci. 2010;32:416-9.

10. Chiem J, Ivanova I, Parker A, Krengel W, Jimenez N. Anaphylactic reaction to tranexamic acid in an adolescent undergoing posterior spinal fusion. Paediatr Anaesth. 2017;27:774-5.

Manuscript received June 24, 2020; accepted for publication October 26, 2020.

Hassan El Hanache

Allergy unit Angers University Hospital 4, rue Larrey 49933 Angers Cedex 9, Angers, France E-mail : hassan.elhanache@gmail.com 